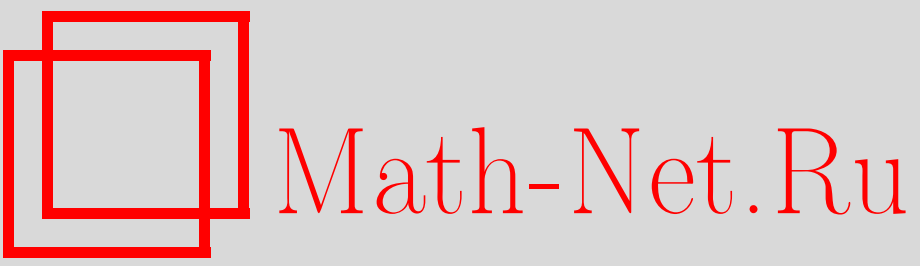

Ю. В. Новожилов, Международная школа физики В.А. Фока, ТМФ, 2002, том 131, номер 1, 3

DOI: https://doi.org/10.4213/tmf1956

Использование Общероссийского математического портала Math-Net.Ru подразумевает, что вы прочитали и согласны с пользовательским соглашением

http://www . mathnet.ru/rus/agreement

Параметры загрузки:

IP : 34.229 .108 .108

26 апреля 2023 г., 16:15:01 


\section{Международная школа физики имени В. А. Фока}

Международная школа физики (МШ $\Phi)$ имени В. А. Фока ведет свою деятельность в рамках программы ЮНЕСКО “Школы физики”, обрашенной к молодым талантливым исследователям из различных стран и призванной способствовать их ознакомлению с последними достижениями науки и взаимодействию с известными учеными и молодыми коллегами из других стран. МШФ проводится на базе Санкт-Петербургского государственного университета в сотрудничестве с Евразийским Физическим обществом. Школа, впервые проведенная в 1991 г., получила имя В. А. Фока в 1998г. в связи со столетием со дня рождения великого русского физика Владимира Александровича Фока даты, которая отмечалась ЮНЕСКО и в России. Как известно, практически вся научная деятельность В. А. Фока проходила в стенах Санкт-Петербургского университета, и Физический институт университета теперь носит имя В. А. Фока.

Школы 2000 г. и 2001 г. были посвящены проблеме "Нелокальные квантовые объекты и методы теоретической физики". Обсуждение этой проблемы на МШФ включало как экспериментальные, так и теоретические доклады по всему спектру нелокальных систем от квантовых точек до квантовых дыр, а также доклады по применению методов теоретической физики к моделированию социальных и экономических процессов. Такой подход к исследованию проблемы был характерен для научного творчества В. А. Фока, который считал, что изучение теоретической физики очень полезно для людей, занимающихся социальными науками, в целях приобретения навыков систематического мьшления. Слушатели и лекторы МШФ представляли разные города России и страны мира.

В настоящем номере журнала публикуются статьи следующих авторов: М. Бордаг, В. Скалозуб; Х. Дош, С. Ю. Славянов; В. Н. Марачевский; В. Б. Матвеев; В. Ю. Новожилов, Ю. В. Новожилов; Б. С. Павлов, А. А. Покровский, А. В. Стрепетов; С. А. Пастон, Е. В. Прохватилов, В. А. Франке; Е. М. Сантанжело. Эти статьи основаны на докладах по теоретической физике, прочитанных на Школе 4-15.ХІІ.2000г. Доклады на секции "Модели реальной жизни", в которых рассматривались калибровочные модели в области финансов, модели роста народонаселения, критические явления в социологии и т.д., будут изданы отдельной книгой.

Оргкомитет Международной школы физики имени В. А. Фока благодарен Редколлегии журнала "Теоретическая и математическая физика" за публикацию ее трудов.

Ю. В. Новожилов

Вице-президент Евразийского физического обшества, Председатель оргкомитета МШФ имени В. А. Фока 